NBER WORKING PAPER SERIES

\title{
INSULATION OF PENSIONS FROM POLITICAL RISK
}

Peter Diamond

Working Paper No. 4895

\author{
NATIONAL BUREAU OF ECONOMIC RESEARCH \\ 1050 Massachusetts Avenue \\ Cambridge, MA 02138 \\ October 1994
}

Paper prepared for the conference Mandatory Pensions: Funding, Privatization and Macroeconomic Policy, Santiago, Chile, January 26-27, 1994. Research supported by the Ministry of Finance, Chile. This paper is part of NBER's research program in Aging. Any opinions expressed are those of the author and not those of the National Bureau of Economic Research.

(C) 1994 by Peter Diamond. All rights reserved. Short sections of text, not to exceed two paragraphs, may be quoted without explicit permission provided that full credit, including (c) notice, is given to the source. 
NBER Working Paper \#4895

October 1994

\title{
INSULATION OF PENSIONS \\ FROM POLITICAL RISK
}

\begin{abstract}
There are many sources of political risk to public provision of pensions. This paper analyzes legislation to alter the retirement income system. This approach naturally recognizes that some changes in the system are good responses to social risks, while others generate such risks. Thus the discussion is in terms of the effect of institutional structure on the likelihood of alternative legislative actions. Particular attention is paid to the roles of automatic pension adjustment and pension professionals in providing insulation. Briefly touched upon is the tendency of legislation to redistribute as a function of the type of system being created.
\end{abstract}

Peter A. Diamond

Department of Economics

Ruom E52.344

Massachusetts Institute of Technology

Cambridge. MA 02139

and NBER 
September 19,1994

Insulation of Pensions from Political Risk

Peter Diamond

\section{Introduction}

There are many sources of political risk to the public provision of pensions. One is the granting of excessive benefits to people retiring when the system is not mature, particularly when combined with promises for future retirees that can not be met. A second is the making of promises to future retirees that can not be met, perhaps because assets that could have financed such benefits have been used for other purposes. A third is excessive responsiveness of benefits to the short-run condition of the government budget. A fourth is excessive responsiveness of benefits to the long-run condition of the government budget. ${ }^{\text {I }}$

The Chilean privatized mandatory pension system appears to provide good insulation against political risks (Diamond and Valdes-Prieto (1993), Diamond (1994)). By good insulation, I mean that we have not seen a number of actions that might have occurred. Under the new system, there has been no large infusion of government funds to preserve the expectations of workers. Since the interest rates earned on the privatized funds have been large and there has been no massive fraud, this may reflect these circumstances as well as the social security structure. There has been no adjustment of pension benefits with the state of the government budget. In 1985 when the government budget was in trouble, the COLA on the old system was frozen, but nothing was changed on the new system. In part this may reflect the fact that benefits being paid were very small; in part it was, I think, politically 
insulated by the fact that the money didn't flow through the government. ${ }^{2}$ There was no use made of the mandatory savings plan to do redistribution, even though there were calls to improve pensions for coal miners. My presumption is that the need to identify a source of financing affected the political outcome. Also I see no reason to anticipate a major crisis as Chile goes through the aging transition. Perhaps, if interest rates go down, the mandatory savings rate will have to change, but that is an adjustment that should happen without a crisis; not without a political struggle, but without a crisis. However, with a single data point so far, it is hard to separate the role of privatization of social security from the particular economic and political climate in Chile, and, of course, the particular political structure at the time of the Pinochet government.

This paper explores the meaning of excessive in the opening paragraph and a description of changes in retirement income systems in terms of risks. It considers alternatives to the Chilean approach that also offer insulation against some of these risks, permitting a consideration of possible tradeoffs of other properties of retirement income systems with the degree of insulation.

The approach taken is the analysis of legislation to alter the retirement income system. This approach naturally recognizes that some changes in the system are good responses to social risks, while others generate such risks. Thus the discussion is in terms of the effect of institutional structure on the likelihood of alternative legislative actions. Particular attention is paid to the roles of automatic pension adjustment and pension professionals in providing insulation. The focus on legislation after the creation of the system omits consideration of the relationship between the approach taken to initiation of the retirement $-2-$ 
income system and the pattern of outcomes. This consideration is briefly touched upon in terms of the tendency of legislation to redistribute as a function of the type of system being created.

To frame the analysis, the paper begins with discussion of the allocation of other risks in the economy. It briefly mentions the income distribution system. There are then three simple models to illustrate patterns of risk bearing and risk creation. This is followed by discussion of constitutional and institutional effects on the patterns of legislation.

\section{Other risks}

We are all familiar with issues of risk bearing in the asset market. Individuals are modeled as facing (and making) choices across different risk-expected return combinations. More important for our purposes is the social allocation that comes with these choices. These have different properties in different market settings. If markets are complete, then the allocation of risk bearing in the asset market is Pareto efficient. However, if markets are not complete, then the allocation is generically not Pareto efficient. ${ }^{3}$ Incomplete markets imply that allocations can be improved upon..$^{4.5}$

In considering efficiency, a critical element is whether the allocation process happens once and for all (with complete markets) or whether there are repeated times of decision making (with incomplete markets). Repeated decision making by multiple economic agents in the presence of a changing ability to choose among alternatives is the source of inefficiencies (in contrast with complete markets). Of course, banning future trades and 
forcing people to stay with whatever incomplete market plans they made earlier is not a cure for inefficiency.

In considering political risk, there are two elements. One is the presence of significant social risk that must be adapted to; a once-and-for-all allocation will not be efficient. Second is the combination of limited complexity in legislation and a lack of commitment devices for government. Taken together, these restrictions are akin to the incomplete market problem in asset markets. When the lack of commitment devices by government has been approached in terms of a time-consistency vocabulary, this has generally been modeled as a game between a government and its citizens. ${ }^{6}$ It seems to me at least as important to recognize the risk associated with political competition as the risk associated with lack of commitment by a single government player. Moreover, in the game context, reputation effects can play a major role in mitigating this time-inconsistency problem. ${ }^{7}$ In any event it has been much studied, so I will concentrate on other issues. These resemble political business cycle issues $^{8}$, although I will view them in the social insurance context.

The mention of time inconsistency in government policy reminds us of the same issue in individual choice. ${ }^{9}$ Once individuals show time inconsistency, it is not generally clear how one wants to do welfare analysis. I think that the same issue arises in the context of repeated democratic decisionmaking that shows time inconsistency because of shifting political outcomes and preferences. But this is an issue that I will not explore. 


\section{Redistribution}

When creating a new retirement income system, distribution issues are inevitably intertwined with other design issues. While it is analytically convenient to ignore distribution issues, they should not go unmentioned. This concern has been well stated by Robert Solow in his AEA Presidential Address:

Most of us are conscious of a conflict that arises in our minds and consciences because, while we think it is usually a mistake to fiddle the price system to achieve distributional goals, we realize that the public and the political process are perversely more willing to do that than to make the direct transfers we would prefer. If we oppose all distorting transfers, we end up opposing transfers altogether. Some of us seem to welcome the excuse, but most of us feel uncomfortable. I don't think there is any very good way to resolve that conflict in practice. (1980, page 1.)

In the realm of redistribution one can ask about the relationship between political insulation of the mandatory savings part of the pension scheme, and political insulation of the redistribution coming from the minimum pension. In Chile, any annuity purchased with mandatory savings must be indexed for inflation, but the minimum pension is not automatically indexed. So there are periodic adjustments. This does not appear to be a good way to design a system aimed at providing to the poor. A more integrated pension system might have had a different balance of insulation of the different parts.

\section{A simple example of risk sharing ${ }^{10}$}

It is natural to examine social provision of retirement insurance in an overlapping generations model." This permits consideration of some issues not present in finite models. Nevertheless, I will consider two period models, for their simplicity. I want to consider three 
examples, reflecting aggregate income risk, pure political risk, and inaccuracy of expectations.

Consider a two-period model with two types of agents. Type A receives income $y_{1}$ in period one, before the government passes any legislation. Type B receives income $y_{2}$ in period two, which is random at the time of period-one legislation, but known before the time of period-two legislation, if any. There is no production and no storage in this economy. Thus the credit market plays a central role in the allocation of resources, representing both a way in which each type obtains consumption in the period without income and the way in which risks of second period income are shared. Each agent seeks to maximize the expected value of the utility function $u^{i}\left(c_{1}^{i}, c_{2}^{i}\right), i=a, b$.

The set of Pareto optimal allocations has both types of agents having the same realized (ex post) intertemporal marginal rates of substitution. (We do not consider allocations where individuals of a given type have different consumption levels.) Thus the Pareto optimal allocations satisfy

$$
\begin{aligned}
& u_{1}^{a}\left(c_{1}^{a}, c_{2}^{a}\right) / u_{2}{ }_{2}\left(c_{1}^{a}, c_{2}^{a}\right)=u_{1}^{b}\left(c^{b}{ }_{1}, c_{2}^{b}\right) / u_{2}^{b}\left(c^{b}{ }_{1}, c^{b}{ }_{2}\right), \\
& c_{1}^{a}+c_{1}^{b}{ }_{1}=y_{1}, \\
& c^{a}{ }_{2}+c^{b}{ }_{2}=y_{2} .
\end{aligned}
$$

The question at hand is how to achieve one of these allocations. One way, from ArrowDebreu theory, is to assume a complete set of markets. That is, consumption in period two, conditional on the level of income in period two is a different good for each possible level of income in period two. We know that the economy does not have this complete set of markets; that it would be very expensive to try to have them; and that the attempt to list all states of nature would fail, since something would happen that was not anticipated. $-6-$ 
Consider next the allocation that occurs if there is only trading in a safe (real) bond. We assume that marginal utility goes to infinity sufficiently quickly with low incomes that individuals never allow themselves to be in a position to go bankrupt. The set of equilibrium allocations, for different lump sum (ex ante) redistributions between the two types, satisfy the equations

$$
\begin{aligned}
& E\left\{u_{1}^{a}\left(c^{a}, c^{a}{ }_{2}\right)\right\} / E\left\{u_{2}^{a}\left(c^{a}{ }_{1}, c_{2}^{a}\right)\right\}=E\left\{u_{1}^{b}\left(c_{1}^{b}, c^{b}{ }_{2}\right)\right\} / E\left\{u_{2}^{b}\left(c^{b}{ }_{1}, c^{b}\right)\right\}, \\
& c^{a}{ }_{1}+c^{b}{ }_{1}=y_{1}, \\
& c^{a}{ }_{2}+c^{b}{ }_{2}=y_{2} .
\end{aligned}
$$

I have assumed that everyone has the same subjective probabilities in taking expectations, $E$, and that these expectations are correct; i.e., everyone knows the true distribution of incomes in period two. We know these allocations (in (2)) are less efficient than those described above with complete markets (in (1)).

Now, let us add to this system a pay-as-you-go (PAYG) social insurance system. In the first period, there is a poll tax $T_{1}$ on type $A$ consumers used to finance a benefit $B_{1}$ for type $B$ consumers. In the second period, the poll tax, $T_{2}$, on type $B$ consumers is used to finance a benefit, $B_{2}$, given to type A consumers. We have simplified the story by having no distortions associated with the social insurance system.

Let us consider restrictions on allowable legislation in period one and the possibility of new legislation in period two. Limited ability to deal with complexity, or equal treatment constitutional restrictions, or the determination of legislated outcomes might require that taxes or benefits or their relationship be the same for each generation. Assuming that the generations are of equal size reduces these possibilities to a single restriction, $T_{1}=T_{2}=B_{1}=B_{2}$. $-7-$ 
In this case, social insurance accomplishes nothing in risk sharing; the allocation is simply one of the allocations in (2), with the given level of redistribution.

One method of introducing risk sharing is to assume that taxes are proportional to income. That is, we introduce proportional taxes, $t_{1}$ and $t_{2}$ rather than the poll taxes. In the first period, the breakeven condition requires $B_{1}=t_{1} y_{1}$. The question is what is legislated in period one for period two. One possibility is to legislate the same tax rate, $t_{1}=t_{2}$, with benefits determined by the PAYG breakeven condition.

If the government does not choose to legislate such an indexed system, then the story becomes more complicated. Let the government choose an income tax rate and benefit level that break even in period one, and legislate both values for both periods. Then, in period two, the government will need to legislate a change in benefits or taxes (or both) almost certainly, if it wants to break even. Provided that people can accurately predict exactly what the government will do in period two and provided that the government, ex post, will do the correct thing from an ex ante point of view, the government can produce an allocation satisfying the full efficiency conditions in (1).

However, we have introduced two complications - what will the government actually do in period two and what will people predict in period one.

\section{A simple example of risk creation}

Let us continue with the same model as above, except that we now assume that second period income is determinate rather than random. There is now no risk-sharing reason for social insurance. There is also no efficiency cost to having a social insurance system of the 
kind described here, provided that first period legislation is not reconsidered in the second period. Such reconsideration introduces political risk from the perspective of individuals. Moreover, perceptions of the possible different outcomes affects the functioning of the capital market, even though there is no taxation of capital market income. ${ }^{12}$ In order to proceed, we need a model of the determination of political outcomes. ${ }^{13}$ And for the purposes of the design of social insurance, a model of the relationship between political outcomes and the social insurance system structure.

To make this issue precise, we now assume that $y_{2}$ is not random, but is not equal to $y_{1}$. (Different population sizes would be a reasonable alternative to consider.) In the first period the government legislates $t_{1}=t_{2}$ and $B_{1}=B_{2}$. This works fine in the first period, $B_{1}=t_{1} y_{1}$, but results in a system with a surplus or deficit in period two, depending on the relative sizes of $y_{1}$ and $y_{2}$. Thus second period legislation is now needed. Let $L$ be a random variable reflecting the uncertainties that impact on the legislative process. Thus we assume that second period legislation yields a tax rate and a benefit level that are functions of $L$, and that satisfy the PAYG break even condition, $B_{2}(L)=t_{2}(L) y_{2}$. In this setup, the credit market in period one depends on expectations about the legislative process. The equality of marginal expected utilities yields the following first order condition for the determination of the level of lending and borrowing, $s$ and the rate of return, $r$.

$$
\begin{aligned}
& \mathrm{E}\left\{\mathrm{u}_{1}^{\mathrm{a}}\left(\mathrm{c}_{1}^{\mathrm{a}}, \mathrm{c}_{2}^{\mathrm{a}}\right)\right\} / \mathrm{E}\left\{\mathrm{u}_{2}^{\mathrm{a}}\left(\mathrm{c}_{1}^{\mathrm{a}}, \mathrm{c}_{2}^{\mathrm{a}}\right)\right\}=\mathrm{E}\left\{\mathrm{u}_{1}{ }_{1}\left(\mathrm{c}_{1}^{\mathrm{b}}, \mathrm{c}_{2}{ }_{2}\right)\right\} / \mathrm{E}\left\{\mathrm{u}_{2}^{\mathrm{b}}\left(\mathrm{c}^{\mathrm{b}}{ }_{1}, \mathrm{c}^{\mathrm{b}}\right)\right\}, \\
& \mathrm{c}_{1}^{\mathrm{a}}+\mathrm{s}=\left(1-\mathrm{t}_{1}\right) \mathrm{y}_{1}, \mathrm{c}_{1}^{\mathrm{b}}{ }_{1}=\mathrm{s}+\mathrm{B}_{1}, \\
& \mathrm{c}_{2}^{\mathrm{a}}=\mathrm{s}(1+\mathrm{r})+\mathrm{B}_{2}(\mathrm{~L}), \mathrm{c}^{\mathrm{b}}{ }_{2}=\left(1-\mathrm{t}_{2}(\mathrm{~L})\right) \mathrm{y}_{2}-\mathrm{s}(1+\mathrm{r}) .
\end{aligned}
$$

$-9-$ 
where expectations are taken over $\mathrm{L}$. The assumption that the social insurance system will not be in balance in period two is not a necessary condition for there to be legislation in period two, or uncertainty about period-two legislation in period one. It does seem more likely that there will be legislation if there is imbalance.

A central question is how the dependence of legislated taxes and benefits, depicted as functions of the random variable $L$, varies with the structure of social insurance put in place in period one. It is natural to divide the question into two pieces - a probability of new iegislation and a relationship between period-two legislation and period-one legislation. For example, if the legislation is in terms of poll taxes, $T$, and benefits so that budget balance can be legislated in advance, it may still happen that these levels are changed in the second period. Having first and second period benefits and taxes the same might minimize the probability of legislation to change their levels. In addition, we would expect second period taxes and benefits to be a (stochastic) function of both what happened in period one and what was voted in period one for period two. That is, the legislated tax, $t_{2}(L)$, is plausibly a function of $t_{1}$ and also of what $t_{2}$ would be if there were no legislation. The inherited legislated outcomes are a default should there be no legislation; this would naturally affect outcomes with bargaining models of legislated outcomes. This setup lends itself to consideration of legislated levels of parameters as functions of previously legislated levels. Below we will turn to the further issue of the relationship of legislation to the structure of the program.

There is a second dimension to this issue if one views the first period legislative process as no more worthy of respect from the analyst than the second period process. If $-10$ 
first period legislation is viewed as unfair in the second period, would a design of the legislative process that prevents its undoing be a good thing?

\section{Perceptions}

In both sections above, we assumed that consumers knew the distributions of both (possibly) random incomes and (possibly) random legislated redistributions. Consumers don't know these distributions; no one does. Thus we need to consider the implications of possibly inaccurate forecasts. For example, consider the model of pure political risk (no aggregate income risk) where the social insurance system legislated in the first period is definitely not viable in the second period. Then, consumers planning their transactions in the capital market must forecast the political outcomes. Thus the equilibrium will satisfy

$$
\begin{aligned}
& \mathrm{E}^{\mathrm{a}}\left\{\mathrm{u}_{1}{ }_{1}\left(\mathrm{c}_{1}^{\mathrm{a}}, \mathrm{c}_{2}^{\mathrm{a}}\right)\right\} / \mathrm{E}^{\mathrm{a}}\left\{\mathrm{u}_{2}^{\mathrm{a}}\left(\mathrm{c}_{1}^{\mathrm{a}}, \mathrm{c}_{2}^{\mathrm{a}}\right)\right\}=\mathrm{E}^{\mathrm{b}}\left\{\mathrm{u}_{1}^{\mathrm{b}}\left(\mathrm{c}^{\mathrm{b}}{ }_{1}, \mathrm{c}^{\mathrm{b}}\right)\right\} / \mathrm{E}^{\mathrm{b}}\left\{\mathrm{u}_{2}^{\mathrm{b}}\left(\mathrm{c}^{\mathrm{b}}, \mathrm{c}_{2}^{\mathrm{b}}\right)\right\}, \\
& \mathrm{c}^{\mathrm{a}}{ }_{1}+\mathrm{s}=\mathrm{y}_{1}-\mathrm{T}_{1}, \mathrm{c}^{\mathrm{b}}{ }_{1}=\mathrm{s}+\mathrm{B}_{1}, \\
& \mathrm{c}^{\mathrm{a}}{ }_{2}=\mathrm{s}(1+\mathrm{r})+\mathrm{B}_{2}, \mathrm{c}^{\mathrm{b}}{ }_{2}=\mathrm{y}_{2}-\mathrm{s}(1+\mathrm{r})-\mathrm{T}_{2} .
\end{aligned}
$$

This allocation differs from the one above in that I have added individual tags to the expectation operator, reflecting the possibility of different beliefs by different consumers (although still assumed the same for everyone of the same type) over the levels of taxes and benefits in the second period. While first period benefits and taxes have been legislated, the second period levels are random variables over which expectations are needed.

\section{Some Hypothetical Examples}

It might be useful to consider some circumstances where each of the above models has some relevance. While it would be best to have some real examples, I will make do with $-11-$ 
hypothetical ones. Consider an economy that is undergoing rapid economic growth so that wages are growing rapidly and returns to capital are high, but the current elderly are not well off, having worked and saved at times of low wages and low rates of return. Possibly a large fraction of the elderly are below the poverty threshold. Politically, it is difficult to raise the minimum pension for elderly to pull many of them out of poverty. But increasing benefits in the PAYG social security system is easy since payroll tax revenues are high. Passing such legislation can be viewed as an example of the model in section 2 since the level of benefits is sensitive to aggregate incomes in a way that tends to move intertemporal marginal rates of substitution toward each other.

As an example of political risk, consider a government that has tax revenues that are more than proportionally sensitive to the business cycle (or are particularly sensitive to other variables). Assume that the government responds to fiscal difficulties by adjusting all expenditures, including retirement pensions. Then, viewing the state of the budget as a random variable, the variation of government provided retirement pensions with the state of the government budget in excess of the variation in other incomes is an example of guvernment created risk that worsens the efficiency of risk bearing. This example differs from simply assuming that two political parties repeatedly change in controlling the government, with one party expanding retirement benefits and the second party reducing them since it identifies a source of variation that suggests additional methods of insulation, rather than just a need for insulation.

In both of these examples, I have identified the pattern of consumption or income per capita as the basis for judging risk reducing and risk increasing changes. This reflects the $-12$. 
economic theory of risk sharing and is the basis for the proposal by Robert Merton that social security benefits be indexed to consumption per capita (Merton, 1983).

In sum, we would like to identify good reasons for varying benefits and taxes and bad reasons for varying them, and then to choose a structure for provision of retirement income that encourages the former and discourages the latter. It is probably worth remembering that encouragement and discouragement are probably the right vocabularies - there are no guarantees in politics.

\section{Legislated Outcomes}

We have identified a pair of needs - the need to modify social security in some circumstances and a need not to modify it in others. Moreover, there is a need for accurate perceptions about the likelihood of both types of circumstances. Thus we want to ask about mechanisms that affect the likelihood of change in the system. We want to ask about the effect of such mechanisms on changes in both circumstances. And we probably want to distinguish between circumstances of increases and circumstances of decreases in both taxes and benefits.

All of the simple models above incorporate some legislated outcomes. At this stage of our knowledge of the determination of legislated outcomes, this process must remain something of a black box, with the argument relying on intuitions of the effect on legislation, rather than derivations from a model of legislation. There are three different types of sources of effects on the legislative process. One source is elements of the constitution that affect how the legislative process works in the consideration of social security; second is the role 
of the social security benefit and cost determination process on likely legislation; third is the role of other factors and institutions on legislative behavior. This can be considered to be the development of a political culture that limits what governments choose to do, even when they could (at least temporarily) do other things. That is, we are distinguishing between changing the rules covering legislation on the one hand from institutions that affect political context.

Of course these issues are not unique to social security. For example, it is interesting to reflect on the recent newspaper articles on the opening up of the Japanese rice market to imports and its effect on incomes of rice farmers. The protection system was politically vulnerable, in part from the rise of countervailing political power (exporters concerned about GATT) and the lack of an independent claim for income protection (other than the historic cultural continuity of Japanese rice). As economists, we may not like the income protection to begin with, but it is still interesting to consider what would have made it more secure. Do tariffs have more (or less) political viability than quotas?

\section{Constitutional Rules}

I will refer to the rules governing the functioning of the legislature as a constitution. These rules affect how a government that continues to live by the constitution might behave, how the constitution might be amended within the constitutional process and how (and whether) the constitution might be replaced by an extra-constitutional process.

There are many actions that governments might take. Any asset might be taken by government. Any expected receipt might be blocked by government. Conversely an asset might be given by government, an expectation that might otherwise be unrealized might be $-14-$ 
fulfilled by government. These are some of the second period legislated acts that might be taken. Let us begin by considering common constitutional restrictions on asset seizure generally.

Some constitutions protect private property and private contractual arrangements by a restriction that government must compensate if it "takes" private property. Of course the definition of a taking is unclear so the implications on behavior of such a rule depend on ongoing political and judicial processes. In addition the definition of "private property" could be manipulated. Similarly, a government contract to purchase an item is normally subject to the same damage-payment rules as a private contract. Thus, one approach to constitutional protection for social security is to give the social security system's promises the same status as private contracts or private property rather than the status of legislated behavior, which is subject to future legislated changes.

Such status would make more difficult the reduction of benefits below the promised level. One would hope that this difficulty in reduction would act to limit promised benefits. This may make predictability a little more difficult since legislated promises would tend to be on the low side. ${ }^{14}$ There are two sides to such a change. Generating such sluggishness in the legislative process may reduce the ability to respond to either the particular risky outcomes that have occurred or a change in the desired outcome (in someone's eyes) while enhancing the protection from pure political risk. However, there is an asymmetry here between benefit increases and benefit decreases. Thus, desired outcomes (in someone's eyes) can be legislated at a time of temporary political power and might be hard to reverse.

$-15-$ 
An alternative approach is to put the rules covering social security directly into the constitution, making changes more difficult since amending a constitution is generally a process requiring greater majorities or additional steps than with ordinary legislation.

\section{Social Security Design}

The full privatization and full funding of a defined-contribution plan, as in the Chilean model, seems to provide the most insulation. This suggests that this insulation should be traded off against other elements, such as the ability to provide insurance and cost. However, this ignores the issue that insulation without limit is not uniformly good. It seems useful to distinguish different degrees of resistance to change along a path connecting a traditional unfunded defined benefit system with the Chilean model.

The minimal design element for public provision of retirement income would be a benefit plan, with no specific identification of a revenue source. Such a system would be very vulnerable to the state of the government budget. Traditionally, a payroll tax is earmarked to pay for the promised benefits. This earmarking offers some insulation from fluctuations in the rest of the budget, although it increases sensitivity to fluctuations in the earmarked source of revenue. Earmarking will generally require periodic legislation to align taxes and benefits unless there is automatic adjustment. Automatic adjustment rules in a totally unfunded system may provide considerable insulation to benefit increases in that any benefit increase requires a simultaneous tax increase, although an immature system will have low tax rates and offer little resistance to such changes. Such an automatic-adjustment mechanism may make the future rise in taxes more visible than in a nonautomatic system. The presence of earmarking affects the likelihood that the revenue will be used for other $-16-$ 
purposes; it also affects the likelihood that other sources of revenue will be used for this expenditure and that the level of earmarked funds will be increased. Thus the absence of a fund may increase insulation in a system where benefits and taxes are adjusted to each other automatically.

It is common for traditional systems to partially fund benefits so that any excess of earmarked revenue over benefits goes into a fund. The presence of a fund does provide some insulation from vagaries in the government budget, but it probably increases the likelihood of benefit increases (possibly unsustainable) on the basis of fund ayailability and also of fund use for other purposes, a more difficult trick if there is no fund.

Funding can be done with public debt. That this is primarily a political act can be seen in the following quotation from Bodie and Merton (1993). In commenting on the social security trust fund buildup in the U. S., they write: "In a private plan, funding is used to insure against default by the plan sponsor. Here the promise to pay benefits has the same level of full faith and credit of the government as the bonds used to fund the plan. Yet there seems to be a belief that this change may help to ensure that, when they reach retirement, workers will indeed receive benefits approximating those promised under the current benefit formula (i.e., the one in effect in 1992)."

There is a role for such a promise in the effect on the legislative process. There are probably different degrees of likelihood in the following actions. A government might repudiate just implicit social security debt, it might repudiate explicit public debt held by the social security system, it might repudiate all government debt, it might seize private assets held by the social security system, it might seize all assets. The idea behind the reduction $-17-$ 
in likelihood comes from the pooling of groups of assets or income claims so that they tend to be treated the same by the legislative process. That is, there tends to be a norm of uniformity, assets or income flows can be taxed, but not at a discriminatory rate - a rate different from other (similar) sources of income or wealth. Insofar as groups are politically accepted as equal, they tend to get treated equally. This does not underestimate the ability of the political system to identify (or create) differences in order to have targeted benefits. By placing retirement income in the same equal treatment category with other forms of income, particularly privately provided retirement income or income from assets generally, there may be more political protection. Again, there may be asymmetry in that it is easier to invoke equal treatment to guard against losses than for the general public to cite it to guard against increased benefits. This is similar to the possibility that the idea of a comprehensive tax base affects the extent to which tax loopholes get legislated.

The next step beyond funding with government debt is funding with private assets. This probably increases the insulation from political risk, although it is a little unclear why private assets may seem more "real" to voters, more of an obligation to continue promised benefits. $^{15}$

From this perspective, a defined contribution system differs from a defined benefit system in that the promised benefits are automatically adjusted to the availability of funds. That is, no further legislative actions are required in order to carry out the promised benefits. This can be done with earmarking without funding. But earmarking without automatic adjustment is not the same as earmarking with automatic adjustment; just as funding a defined benefit system is different from funding a defined contribution system. $-18-$ 
In addition to the issue of automatic adjustment, there is an issue of the visibility of the automatic adjustment. In defined contribution systems, benefits are automatically adjusted to measures of the performance of the economy. This adjustment is not very visible since it is done at the time of setting benefits, rather than changing their level. It is even less visible if it is set by the "market." I think that a legislature would have difficulty trying to change the relationship between annuities and accumulations on a year by year basis. This adjustment seems to need to be out of sight of the public. It seems to me that visibility in the public arena is a two-edged sword. Visibility prevents some kinds of bad political action: It is a little harder to steal in the light of day then it is at night. Forcing identification of who pays for a new benefit is a form of increased visibility. But higher visibility will also tend to limit good professional reactions. Thus it may be useful to try to build a respected professional expertise, somewhat insulated from political pressures, that can try to guide the system into the kinds of changes that ought to happen. Thus the Chilean system seems to provide insulation by having added visibility as a result of individual accounts and by having decreased visibility from the absence of a stated benefit formula.

It is natural to think of an annuity market as adjusting benefits to available resources, but there is no need for the resources to be physically present. That is, the benefits could be adjusted to various accounting measures that have no backing in physical assets. This is essentially what Boskin, Kotlikoff and Shoven (1988) propose. In their system, each year people accrue additional (real) benefits (on retirement) based on that years taxes paid. However the accrual rates are set by actuaries based on forecasts so that the system is forecasted to be in balance over the projection period. By doing these adjustments on an $-19$ 
annual cycle affecting current contributors and not current beneficiaries, it is much easier to preserve the professional character of these calculations from political forces. Having many small decisions should make this process even less visible than a single decision. Lack of visibility is insulation for professionalism, but it can also be insulation for theft.

Contrast this approach with one that adjusts annual benefits to annual revenues by proportionally changing all benefits to be paid that year. While benefit recipients might be passive in the face of such announcements, it is more likely that there will be pressure on politicians and so pressure on the system from politicians to protect benefits. There will also be pressure to enlarge entitlements on the ground that actual benefits will be cut in the future. Taking away from people what they do not realize they have is much easier. Similarly, the public seems to think largely in nominal terms, so that reductions in cost-of-living adjustments are politically easier than adjustments in benefit levels, however curious this distinction is to economists. Of course, this is the sort of political evaluation that may not have long run viability, since the degree of understanding of the nominal-real distinction and its political acceptance by the public could change.

More generally, the degree of money illusion (inflation illusion) in the public depends on history, particularly exposure to inflation. Thus, in some inadequately indexed social security systems, protecting retirement incomes from inflation is an important part of protecting retirement incomes. The obvious institutional response is to have an indexed system. However, even an indexed system is somewhat vulnerable to sufficiently high inflation rates because of lags. There may be no direct cure for this, with avoidance of high inflation the obvious solution.

$-20-$ 


\section{$\underline{\text { Political Context }}$}

In addition to constitutional changes and different choice of parameters in the insurance institution, there are other ways to affect the distribution of legislated outcomes. One is by adding an institution that has some of the powers of the legislative body (but subject to override by the legislature), for example an institution with some of the workings of independent central banks. Such an institution is then charged with setting some parameters of social security and staffed with independent professionals. ${ }^{16,17}$

In addition to having direct control of some parameters, an institution with professional independence can affect the dialogue about social security. Having an official actuarial office that is required to report annually and/or to comment on any proposed legislation gives higher political visibility (and presumably resistance) to changes that may be unsustainable. In the US the Office of the Actuary in Social Security must forecast the financial balance of the system for 75 years. While it is easy to ignore these pronouncements, this does give a little more political prominence to these long run issues.

With privatized management of a separate trust fund, there is again a set of professionals to comment on proposed legislated changes in the private fund managers.

Another approach to affecting political outcomes is by changing the description of the system in the eyes of the public. For example, the vocabulary of individual accounts (as opposed to a benefit formula) has suggestions to the public that may affect legislated outcomes. Referring to social security as a tax-transfer mechanism in ordinary discourse may make the system more vulnerable than referring to it as an insurance system, one where benefits have been earned by paying earlier premiums. Such a conversational change results $-21-$ 
in a primarily one-sided protection - harder to cut benefits, but not harder to raise them. If the greater risk is increases that result in unsustainable benefit levels, then this does not offer much protection.

An additional area where vocabulary matters is the vocabulary of government budget balance. One example of a subtler form of pressure is the public definition of the budget balance - whether this includes or excludes the social security system. To get some insulation from the short run fluctuations in the state of the government budget, one can move the social security receipts and expenditures outside the budget. This can be done in a variety of ways with differing degrees of insulation. One can simply not include social security in official definitions of the budget deficit. One role for earmarking and a trust fund is to add to the sustainability of such a vocabulary choice. An independent institution managing the fund may also add to this sustainability.

The political viability of an arrangement can also depend on the circumstances of its creation. If people do pay for the assets that go into their accounts, these accounts may be politically more insulated than if they are given such accounts. Perceived fairness has some political effects. So too does clearly perceived unfaimess.

Working in an exchange economy has kept my analysis focused on risk, the central charge of this paper. ${ }^{18}$ Capital accumulation is a major issue in the behavior of governments. Some of the academic support for funding comes from a desire to see more capital accumulation, not from concern with insulation. A similar analysis might be done of the capital accumulation question. Consider a three period model. One can consider the extent to which one wants more or less capital accumulation than occurs in equilibrium in each of $-22-$ 
the first two periods. One can consider how the level of capital accumulation that occurs depends on institution design in both that period and earlier periods. The government has many tools to affect capital accumulation, of which funding retirement pensions is just one. Thus one needs to consider the relative merits of funding different activities, as well as other institution designs that affect capital accumulation. For example one might try to inculcate the idea that national defense is shaky unless future defense expenditures are funded. The politics of such an institution would probably work differently from one focused on retirement income.

\section{Conclusion}

Right now, the two most visible risks to retirement income (other than through risks to the entire economy and society ${ }^{19}$ ) are the risks of oversensitivity to the state of the government budget and the risk of excessive redistribution to early generations, masked in an unsustainable formula. The Chilean structure does well with both of these problems by moving retirement incomes outside the government budget and by seeming to require the identification of an explicit source of financing for benefits for any group of individuals. It is probably too soon to rule out the ability of the political system to tap these resources for government revenue needs or for redistributions. Requiring investment in government debt, particularly debt paying less than market rates is the obvious route for the former. k.edistributing part of the retum on portfolios to "needier" accounts (which may have an age component) is one route for the later. Protection against such moves probably lies in the identification of individual accounts (and the returns on them) as private property, entitled 
to the same protection as other assets. If this is correct, then the public conception of the retirement income system plays an important role along with the actual institutional structure.

These considerations suggest a value in the creation of an institution giving status and visibility to professional evaluation of the condition of the retirement system and possible changes in it. Since some systems are easier to communicate to the public, such systems are more easily protected by such an institution.

Ongoing defined benefit systems are probably in greater need for protection than are defined contribution systems. Automatic adjustment rules (or adjustment by independent professionals) may help provide more protection for such systems.

It would be good to have a more factual basis on the behavior of legislatures toward retirement systems in different settings in order to identify the set of risks more carefully and to be less speculative about the legislative process in thinking about this important topic. 


\section{Appendix. A Funded System}

I started with a pure exchange economy to highlight the issue of risk sharing and risk creating behavior of legislatures in a setting where there was little else (besides redistribution) happening in the economy. The use of a fully funded system does not change the possibilities of legislative actions to create risks or share them, although it impacts on the likely pattern of outcomes of legislative action and inaction.

To make this point formally, I want to consider a two-period economy with two groups of savers who do not interact with each other in the private market. The two groups can be considered the present generation and future generations. Lumping all of the future into a single generation ignores many issues of the carryover of institution design into the future, but does bring out some issues in a simple setting.

Consider a two period model with two types of agents. Type A receives income $y^{a}$ in period one, before the government passes any legislation. Type B receives income $\mathrm{y}^{\mathrm{b}}$ in period one, but this income is random at the time of period-one legislation, but known before the time of period-two legislation, if any. There is a stochastic linear technology for converting first period income into second period income. Let $R^{\mathbf{b}}$ and $R^{b}$ be the quantities of period-two income received for each unit of period-one income saved by the two types. The two groups can not trade with each other, so each makes its savings decisions based on its (stochastic) options. Thus the credit market plays no role in the allocation of risks between the groups. Direct investment separately by each group is the way that each type 
obtains consumption in the second period and the way in which risks of second-period income are determined.

Each agent seeks to maximize the expected value of the utility function $u^{i}\left(c_{1}^{i}, c_{2}^{i}\right)$, $\mathrm{i}=\mathrm{a}, \mathrm{b}$ subject to the budget constraint $\mathrm{c}_{2}^{\mathrm{i}}=\left(\mathrm{y}^{\mathrm{i}}-\mathrm{c}_{1}^{\mathrm{i}}\right) \mathrm{R}^{\mathrm{i}}, \mathrm{i}=\mathrm{a}, \mathrm{b}$. In keeping with the interpretation of the model, we assume that the government can not alter the levels of investment, but can risk share by setting up a rule transferring between the two groups in period two as a function of the realized rate of return. Using this formulation has individual savers recognize the presence of random transfers, but does not alter the rate of return on marginal investments. Thus the budget constraint of each group is altered to read $c_{2}^{i}=\left(y^{i}-c_{1}^{i}\right) R^{i}+B^{i}\left(R^{a}, R^{b}\right), i=a, b$; with the constraint on the government $B^{a}\left(R^{a}, R^{b}\right)+B^{b}\left(R^{a}, R^{b}\right)=0$.

Purely risk-sharing legislation would have $E\left\{B^{2}\left(R^{a}, R^{b}\right)\right\}=0$. Redistribution from the future to the present generation would have this expectation positive. Legislation with a zero expected benefit level would be risk sharing or risk creating depending on whether it tended to move the intertemporal marginal rates of substitution towards each other or away from each other (as with pure political risk as discussed above).

$-26-$ 


\section{References}

Aghion, Philippe, and Patrick Bolton, 1990, Government domestic debt and the risk of default: a political-economic model of the strategic role of debt, in R. Dornbusch and M. Draghi ,eds., Public Debt Management: Theory and History Cambridge: Cambridge University Press.

Ainslie, George, 1992, Picoeconomics: The Strategic Interaction of Successive Motivational States within the Person, Cambridge: Cambridge University Press.

Alesina, Alberto, 1988, Macroeconomics and Politics, NBER Macroeconomics Annual.

Bodie, Zvi, Alan J. Marcus, and Robert C. Merton, 1988, Defined Benefit versus Defined Contribution Plans: What are the Real Trade-offs?, Chapter 5 in Z. Bodie, J. Shoven and D. Wise (eds.), Pensions in the U. S. Economy, Chicago: University of Chicago Press.

Bodie, Zvi, and Robert C. Merton, 1993, Pension Benefit Guarantees in the United States: A Functional Analysis, in R. Scmitt (ed.), The Future of Pensions in the United States, University of Pennsylvania Press.

Boskin, Michael J., Laurence J. Kotlikoff, and John B. Shoven, 1988, Personal Security Accounts: A Proposal for Fundamental Social Security Reform, in Susan M. Wachter (ed.), Social Security and Private Pensions, Lexington, Massachusetts: Lexington Books.

Cukierman, Alex, 1992, Central Bank Strategy, Credibility, and Independence: Theory and Evidence, Cambridge: MIT Press. 
Diamond, Peter A., 1994, Privatization of Social Security: Lessons from Chile, in Revista de Analisis Economico.

Diamond, Peter A., and James A. Mirrlees, Optimal Taxation of Identical Consumers when Markets are Incomplete, in P. Dasgupta, D. Gale, O. Hart, and E. Maskin, eds., Essays in Honor of Frank Hahn (Cambridge: MIT Press, 1992).

Diamond, Peter A., and Valdes-Prieto, Salvador, 1993, "Social Security Reform," in The Chilean Economy: Policy Lessons and Challenges, B. Bosworth, R. Dornbusch and R. Laban (eds.), Washington: Brookings Institution.

Gale, Douglas, 1990, The Efficient Design of Public Debt, in R. Dornbusch and M. Draghi, eds., Public Debt Management: Theory and History, Cambridge: Cambridge University Press.

Geanakoplos, John and Heraklis Polemarchakis, 1986, Existence, Regukarity, and Constrained Suboptimality of Competitive Allocations when the Asset Market is Incomplete, in W. Heller, R. Starr, and D. Starrett (eds.), Essays in Honor of Kenneth Arrow, 3, 65-95, Cambridge: Cambridge University Press.

Geanakoplos, John, M. Magill, M. Quinzii, and J. Dreze, 1990, Generic Inefficiency of Stock Market Equilibria, Journal of Mathematical Economics, 19, 113-151.

Kydland, Finn E., and Edward C. Prescott, 1977, Rules Rather Than Discretion: The Inconsistency of Optimal Plans, Journal of Political Economy, 85, 3, 473-492.

Loewenstein, George, and Jon Elster, 1992, Choice Over Time, New York: The Russell Sage Foundation. 
Malinvaud, Edmond, 1972, The Allocation of Individual Risks in Large Markets, Joumal of Economic Theory, 4, 2, 312-328.

Merton, Robert C., 1983, On Consumption-Indexed Public Pension Plans, Chapter 10 in Z. Bodie and J. Shoven, eds., Financial Aspects of the U.S. Pension System, Chicago: University of Chicago Press.

Merton, Robert C., and Zvi Bodie, 1992, On the Management of Financial Guarantees, Financial Management, 21, 4, 87-109.

Nordhaus, William, 1989, Alternative Approaches to the Political Business Cycle, Brookings Papers on Economic Activity, 2.

Schelling, Thomas, 1984, Self Command in Practice, in Policy and in a Theory of Rational Thought, American Economic Review, 74 (2), 1-11.

Social Security Technical Panel, 1991, Report to the 1991 Advisory Council on Social Security, Washington, DC: 1991 Advisory Council on Social Security.

Snlow, Robert M., 1980, On Theories of Unemployment, American Economic Review, 70, $1,1-11$.

Stokey, Nancy, 1989, Reputation and Time Consistency, American Economic Review, 79 (2), 134-139.

Strotz, Robert H., 1955, Myopia and Inconsistency in Dynamic Utility Maximization, Review of Economic Studies, 23, 165-180. 


\section{Endnotes}

1. This paper will not consider the risks to the rest of government budgeting from the financial condition of the retirement system.

2. The fact that the funds do not flow through the government does not guarantee that they are not particularly vulnerable. Since the earnings on pension assets are particularly easy to tax, because in the short run it is very hard to do tax evasion, they might have been subjected to special taxes.

3. Geanakoplos and Polemarchakis (1986), Geanakoplos, Magill, Quinzii, and Dreze (1990).

4. There is a similar, although less studied, tradeoff in the labor market. In choosing careers, individuals are choosing different risk-expected return tradeoffs as well. Pursuing some careers is far riskier than pursuing others. Again, incomplete markets imply a lack of Pareto efficiency in general.

5. The literature on insurance normally assumes that there is no social risk, and then explores the role of insurance markets in spreading individual risks (Malinvaud, 1972). Once there are social risks, then the allocation may have different properties.

6. Kydland and Prescott (1977).

7. Stokey (1989).

8. Alesina (1988), Nordhaus (1989).

9. Ainslie (1992), Strotz (1955), Schelling (1984), and the collection edited by Loewenstein and Elster (1992)).

10. There are large aggregate risks associated with the provision of retirement income. 
For example, in the US, the annual percentage reduction in age-adjusted central death rates for males was $-0.19 \%$ for $1954-1968$, but $1.56 \%$ for $1968-1988$ (Social Security Technical Panel, 1991).

11. For a discussion of the use of public debt to share risks in an OLG model with incomplete markets, see Gale (1990). For a discussion of optimal taxation in a Ramsey economy with incomplete markets and social risk, see Diamond and Mirrlees (1993).

12. If there were real investments, with random aggregate returns, then full risk sharing would depend on two sources of risky income. Similarly, if type A's received random income in period two, with a different random structure and an identifiably different character (from the perspective of political identification) we would again have two sources of income risk. For a setup of this model with real investments, see the appendix.

13. I will treat the political process as random relative to social security. That is, I assume that proposed changes in social security do not play a major role in the determination of political outcomes. For a model that determines voting for political parties as a function of the tax, expenditure, and debt policies the parties will follow, see Aghion and Bolton (1990). 14. For example, before the U.S. system was indexed, the benefit formula and the calculation of lifetime average wages were both in nominal terms, making for periodic increases in benefits in response to inflation. This was not a satisfactory system.

15. The use of private assets does affect the nature of political process since the rate of return may well be different - even if the aggregate return to the economy is unchanged, and returns on the funds probably affect legislated outcomes on benefits.

16. For a discussion of independent central banks, see Cukierman (1992). 
17. For example, in the proposal of Boskin, Kotlikoff and Shoven (1988), actuaries set Lhe rate of conversion of current taxes paid into claims on annuitized retirement income.

18. A model with capital is briefly presented in the appendix.

19. Civil war is tough on publicly provided retirement income. 